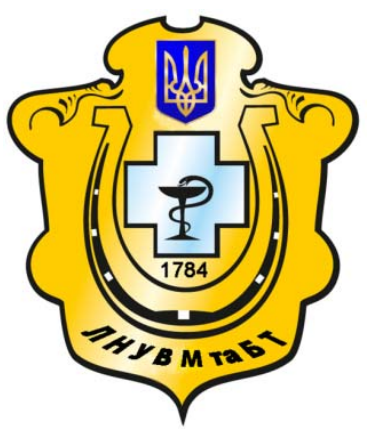

Науковий вісник Львівського національного університету ветеринарної медицини та біотехнологій імені С.3. Гжицького

Scientific Messenger of Lviv National University of Veterinary Medicine and Biotechnologies named after S.Z. Gzhytskyj

doi:10.15421/nvlvet7153

ISSN 2413-5550 print

ISSN 2518-1327 online

$\underline{\text { http://nvlvet.com.ua/ }}$

УДК 619:616.8:636.7

\title{
Основні неврологічні симтоми та їх поширення у собак
}

\author{
В.Л. Федорович, Л.Г. Слівінська, Н.М. Федорович \\ hypiatr@gmail.com
}

\begin{abstract}
Львівський наџіональний університет ветеринарної медицини та біотехнологій імені С.З. Гжсиџького, вул. Пекарська, 50, м. Львів, 79010, Украӥна
\end{abstract}

За результатами амбулаторного прийому було досліджено 12233 тварин, з них 5653 (46,2\%) були собаки. При неврологічному досліджені у 653 собак (11,5\%) виявили симптоми ушкодження нервової системи. Зокрема встановлено, щзо найбільш поширеними неврологічними симптомами у собак були парези та паралічі $(23,4 \%)$. Кількість тварин із нахилом голови, атаксіями, міоклоніями та епілептоформним станом становила відповідно 19,8; 14,7; 11,7; та 10,5\%. Прояви ушкодження нервової системи у вигляді ністагму, кульгання та тремору реєстрували відповідно у 8,3; 4,4 та 4,1\% хворих собак. Найменшу кількість виявляли собак із розладом зору (2,8\%) та слуху (0,3\%), шуо було пов'язано із патологією нервової системи. Зазначені вище симптоми захворювань нервової системи не зустрічалися у вигляді одного симптому, а відмічалися їх поєднання - синдроми. Проведення неврологічного дослідження дає можливість встановлювали локалізацію патологічного процесу у відділах нервової системи (нейроанатомічна локалізація).

Ключові слова. собаки, симптоми, неврологічне дослідження, судоми, атаксія, парези, паралічі, ністагм, нахил голоBu.

\section{Основные неврологические симптомы и их распространения в собак}

\author{
В.Л. Федорович, Л.Г. Сливинская, Н.М. Федорович \\ hypiatr@gmail.com
}

\begin{abstract}
Львовский национальный университет ветеринарной медицины и биотехнологий имени С.3. Гжицякого, ул. Пекарская, 50, г. Львов, 79010, Украина
\end{abstract}

По результатам амбулаторного приема было исследовано 12233 животных, из них 5653 (46,2\%) были собаки. При неврологическом исследовании в 653 собак (11,5\%) обнаружили симптомы повреждения нервной системы. В частности, установлено, что наиболее распространенными неврологическими симптомами у собак были парезы и параличи (23,4\%). Количество животных с наклоном головы, атаксией, миоклонией и эпилептоформным состоянием составляло соответственно 19,8; 14,7; 11,7; и 10,5\%. Проявления повреждения нервной системы в виде нистагма, хромоты и тремора регистрировали соответственно в 8,3; 4,4 и 4,1\% больных собак. Наименьшее количество было собак с расстройством зрения $(2,8 \%)$ и слуха $(0,3 \%)$ связанных с патологией нервной системы. Указанные выме симптомы заболеваний нервной системы не встречались в виде одного симптома, а отмечалась их сочетание - синдромы. Проведение неврологического исследования дает возможность установить локализацию патологического проиесса в разных отделах нервной системы (нейроанатомическая локализачия).

Ключевые слова. собаки, симптомы, неврологическое исследование, судороги, атаксия, парезы, параличи, нистагм, наклон головы.

\section{Basic neurological symptoms and their extension in dogs}

\author{
V. Fedorovych, L. Slivinska, N. Fedorovych \\ hypiatr@gmail.com
}

Citation:

Fedorovych V., Slivinska L., Fedorovych N. (2016). Basic neurological symptoms and their extension in dogs. Scientific Messenger LNUVMBT named after S.Z. Gzhytskyj, 18, 3(71), 240-243. 


\section{Lviv National University of Veterinary Medicine and Biotechnologies named after S.Z. Gzhytskyi,}

Pekarska Str., 50, Lviv, 79010, Ukraine

As a result of the ambulatory reception it was investigated 12233 animals, of which 5653 (46.2\%) were dogs. In the neurological research it had shown the symptoms of the nervous system damage in 653 dogs (11.5\%). In particular it was found that paresis and paralysis (23.4\%) were the most common neurological symptoms in dogs. Number of animals with inclination of head, ataxia, myoclonus and epileptiform state was respectively 19.8; 14.7; 11.7 and 10.5\%. The manifestations of the nervous system damage as nystagmus, tremor and lameness were registered in accordance with 8.3; 4.4 and 4.1\% of sick dogs. The least number of dogs were with a disorder of vision (2,8\%) and hearing (0,3\%), which was associated with the pathology of the nervous system. The above mentioned symptoms of the nervous system diseases do not occur as a symptom, but it was marked their combination - syndromes. The conducted neurological research makes it possible to establish the location of the pathological process in the departments of nervous system (neurons anatomical localization).

As a result of the research and the results found that most dogs manifest the symptoms of damage to the brain and spinal mozkupaytiyi. Based on the results of verification of the diagnosis will be made using the methods of visual diagnostics.

Key words: dogs, symptoms of neurological studies, seizures, ataxia, paresis, paralysis, nystagmus, inclination of the head.

\section{Вступ}

Ветеринарна неврологія як самостійна дисципліна у європейських ветеринарних вузах сформувалася у 90-х роках і висвітлює проблеми неврологічних захворювань у тварин. Широке впровадження в практику ветеринарної медицини візуальних та функціональних методів дослідження нервової системи виявляє нові захворювання, розкриває невідомі ланки патогенезу, а також змінює принципи лікування (Levchenko et al., 2004; Michael et al., 2011).

Багато захворювань нервової системи супроводжується складним поєднанням симптомів, відхиленнями у лабораторних показниках від норми, що створює труднощі у встановленні діагнозу. Застосування принципу проблемно-орієнтованого підходу (по Uide) в розпізнанні неврологічних хвороб та виявлення місця ушкодження (локалізація, топічна діагностика) дає можливість встановити діагноз (Braund, 1994; Michael et al., 2011).

Враховуючи зазначене, вивчення поширення хвороб нервової системи, клінічних ознак, а також виявлення їх поєднання у собак мають важливе практичне значення.

Мета дослідження. Вивчити основні неврологічні симптоми, їх поширення у собак та систематизувати синдроми на основі топічної діагностики.

\section{Матеріал і методи досліджень}

Дослідження проводилися на базі клініки внутрішніх хвороб тварин, а також клінік дрібних тварин м. Львова - ВЦ «VetMed», ВК «EuroVet» та КВМ «Зоовіт». Поширення вивчали протягом двох років при здійсненні амбулаторного прийому хворих тварин, а також згідно реєстрації у ветеринарному програмному забезпеченні.

Для виявлення неврологічних симптомів використовували методи загального клінічного та неврологічного дослідження собак.

\section{Результати та їх обговорення}

Хвороби нервової системи у тварин діагностують за результатами загально клінічного та неврологічного досліджень. Поділ дослідження тварини на дві частини дає можливість ідентифікувати симптоми, що пов'язані із захворюваннями внутрішніх органів та ураженням нервової системи (Braund, 1994; Levchenko et al., 2004; Dewey and Curtis, 2008; Olbi, 2015). За результатами неврологічного дослідження встановлювали локалізацію патологічного процесу (ушкодження) у відділах нервової системи (нейроанатомічна локалізація).

В ході амбулаторного прийому у даних клініках було досліджено 12233 тварин, з них 5653 (46,2\%) були собаки. При неврологічному досліджені у 653 собак $(11,5 \%)$ виявили симптоми ушкодження нервової системи.

Найпоширенішим неврологічним симптомом були парези та паралічі (табл. 1), які виявили у 23,4\% (153) собак, що вказує на первинну моторну дисфункцію спричинену неврологічними розладами (Dewey and Curtis, 2008; Michael et al., 2011; Olbi, 2015). При клінічному дослідженні їх необхідно диференціювати від патології опорно-рухового апарату (симптом кульгання) (Michael et al., 2011; Olbi, 2015).

Таблиия 1

Найпоширеніші симптоми хвороб нервової системи у собак

\begin{tabular}{|l|c|c|}
\hline \multirow{2}{*}{\multicolumn{1}{|c|}{ Симптоми }} & \multicolumn{2}{c|}{$\begin{array}{c}\text { Кількість собак } \\
(\mathrm{n}=653)\end{array}$} \\
\cline { 2 - 3 } & всього & у відсотках \\
\hline Парези, паралічі & 153 & 23,4 \\
\hline Нахил голови & 129 & 19,8 \\
\hline Атаксії & 96 & 14,7 \\
\hline Міоклонії & 76 & 11,7 \\
\hline $\begin{array}{l}\text { Епілептоформний стан } \\
\text { (судоми) }\end{array}$ & 69 & 10,5 \\
\hline Ністагм & 54 & 8,3 \\
\hline Кульгання & 29 & 4,4 \\
\hline Тремор & 27 & 4,1 \\
\hline Розлади зору & 18 & 2,8 \\
\hline Розлади слуху & 2 & 0,3 \\
\hline
\end{tabular}

Кількість собак із кульганням нейрогенного походження становила 4,4\% (табл. 1). Даний симптом завжди вказує на захворювання опорно-рухового апарату але якщо при цьому відмічається пропріорецептивний дефіцит, тоді необхідно провести неврологічне дослідження (Michael et al., 2011).

Нахил голови - це зміна іiі позиції, що обумовлено односторонньою втратою тонусу м'язів шиї, які протидіють гравітації (Levchenko et al., 2004; Michael 
et al., 2011; Olbi, 2015). Його відмічали у 19,8\% собак (рис. 1; табл. 1). Ступінь вентрального нахилу вуха може коливатися від декількох градусів до 45. Напрямок його нахилу в більшості випадків відповідає стороні, на якій знаходиться ушкоджена ділянка вестибулярного апарату i вказує на його патологію окрім випадків парадоксальних вестибулярних порушень (Braund, 1994; Mark et al., 2005; Michael et al., 2011). Існують чотири основних нейроанатомічні структури, що пов'язані 3 вухом: лицевий нерв, очний симпатичний тракт, вестибулярні рецептори та равлик. Їхнє ушкодження викликає неврологічні ознаки (Mark et al., 2005; Dewey Curtis, 2008) [5-6].

Атаксія - розлади координації рухів із збереження чутливості. Її виявляли у 14,7\% собак (табл. 1). За даних літератури (Braund, 1994; Mark et al., 2005; Michael et al., 2011) відповідно до нейролокалізації розрізняють три види атаксії - мозочкова, пропріорицептивна та вестибулярна. Така класифікація дає можливість виявити зміни у конкретному відділі нервовлої системи (Michael et al., 2011). При цьому у 54 собак відмічали пропріоцептивну атаксію, у 25 - вестибулярну та у 12 - мозочкову.

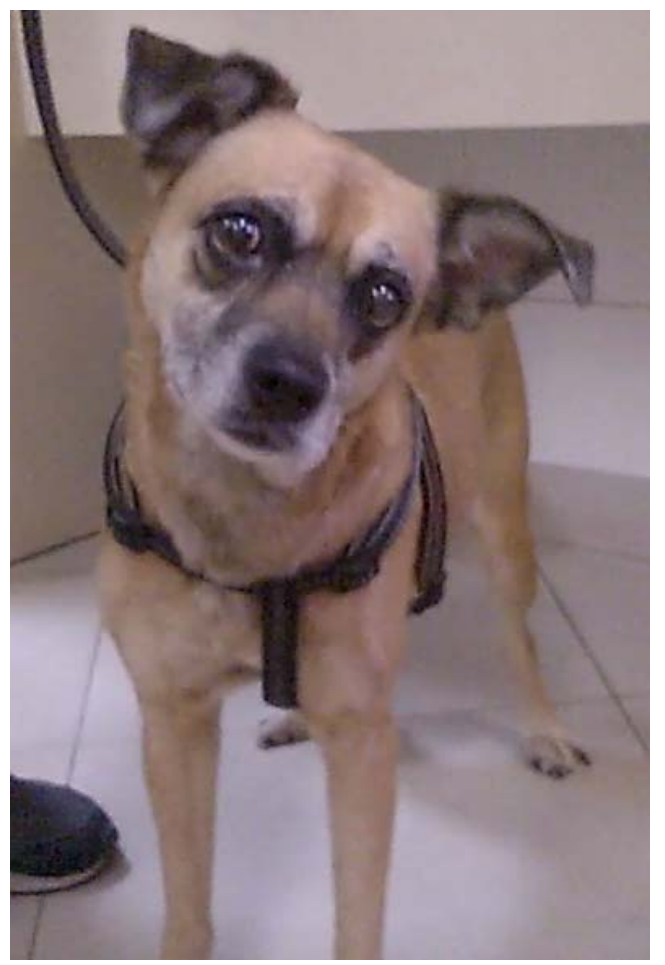

\section{Рис. 1. Нахил голови у собаки}

Міоклонії виявляли у 11,7\% собак (табл. 1). Міоклонія - це спонтанні хаотичні скорочення окремих м'язів або їх груп. В досліджуваних собак діагностували патологічні генералізовані міоклонії, в одному випадку виявлено локальну - скорочення м'язів щоки. Наявність мимовільних скорочень м'язів в поєднанні із атаксією, парезами або паралічами дає підставу запідозрити вірусні ушкодження нервової системи (чума м'ясоїдних).
Кількість собак із судомами становила 10,5 \% (табл. 1). Епілептоформний стан (судоми) завжди вказує про нейроанатомічну локалізацію, а саме, ушкодження ділянки в передньому мозку (кора півкуль) (Michael et al., 2011; Malte et al., 2013; Ghormley et al., 2015). Судоми діагностували за гепатоенцефалопатії, неінфекційних мінінгоенцефалітів, уремічного синдрому, отруєння ізоніазидом та ідіопатичній епілепсії.

При дослідженні очного яблука виявляли патологічні рухи - ністагм, який вказує на ушкодження стовбуру головного мозку, розлади функції черепномозкових нервів (Levchenko et al., 2004; Michael et al., 2011). Тремтіння очей діагностували у 8,3\% собак (табл. 1) за струсу головного мозку та переферичного вестибулярного синдрому.

Тремор - це скорочення м'язів невеликої сили, які нагадують тремтіння (Levchenko et al., 2004). Його відмічали у 4,1\% собак (табл. 1), переважно породи мальтійська болонка. Тремор $\epsilon$ найбільш характерною ознакою ушкодження мозочка (Levchenko et al., 2004; Michael et al., 2011).

Порушення зору спричиняється патологією ока або нервової системи (Michael et al., 2011). Для диференційної діагностики проводили офтальмологічне та неврологічне дослідження. Розлади зору, що пов'язані із захворюваннями нервової системи виявляли у 2,8\% (табл. 1). У більшості випадків інформація від власника може бути хибною, оскільки поведінка тварини, що знаходиться у звичному для нього середовищі, з боку здаватися звичною, навіть якщо вона повністю втратила зір (Braund, 1994; Levchenko et al., 2004; Dewey, 2008; Michael et al., 2011).

У 2 собак $(0,3 \%)$ було виявлено втрату слуху, що поєднувалося із вестибулярним синдромом (табл. 1). У більшості випадків порушення слуху клінічно розпізнаються у випадку двостороннього його втрати. Окрім того ушкодження головного мозку, що призводить до втрати слуху рідкісні, а для їх виявлення проводиться BAER-тест (енцефалографічна перевірки слуху методом викликаних потенціалів) (Braund, 1994; Michael et al., 2011).

Всі зазначені вище прояви захворювань нервової системи не зустрічалися у вигляді одного симптому. Відмічалося їх поєднання - синдроми (табл. 2). Повне неврологічне дослідження дає можливість виявляти та локалізовувати патологічні зміни у певному відділі нервової системи.

В основі принципу формування синдромів захворювань нервової системи ряд авторів (Levchenko et al., 2004; Michael et al., 2011) приймає iii анатомічну будову, що при неврологічному дослідженні спрощує топічну діагностику (табл. 2). В той же час різноманіття симптомів, наприклад при захворюваннях м'язів відмічається вторинні неврологічні симптоми, втягують у патологічний процес інші органи та системи. Тому існує принцип формування синдромів по клінічному прояву - церебральний, вестибулярний, цервікальний, міопатичний та інші (Braund, 1994). 
У даному дослідженні використано принцип нейролокалізації, оскільки він не лише виявляє патологі- чний процес, а й дає змогу пояснити появу того чи іншого симптому та синдрому в цілому (табл. 2).

Табличя 2

Синдроми хвороб нервової системи та їх локалізація у собак

\begin{tabular}{|l|l|}
\hline \multicolumn{1}{|c|}{ Синдроми } & \multicolumn{1}{|c|}{ Локалізація } \\
\hline Судоми, зміна ментального статусу & Кора великих півкуль \\
\hline Зміна ментального статусу & Проміжний мозок \\
\hline Зміна ментального статусу, ністагм, розлади дихання & Стовбур головного мозку \\
\hline Атаксія, дизметрія, дизкоординація, нахил голови & Центральна частина вестибулярного апарату \\
\hline Атаксія, ністагм, дизкоординація & Периферична частина вестибулярного апарату \\
\hline Атаксія, дизкоординація, тремор & Мозочок \\
\hline Ністагм, страбізм, розлади зору, птоз, міоз та мідріаз & Черепно-мозкові нерви, вестибулярний апарат \\
\hline $\begin{array}{l}\text { Порушення ходи, парези та паралічі, розлади діурезу та } \\
\text { дефекації }\end{array}$ & Сегменти спинного мозку \\
\hline Монопарез та монопараліч, порушення ходи, мідріаз, птоз & Периферичні та черепно-мозкові нерви \\
\hline
\end{tabular}

\section{Висновки}

В результаті проведених досліджень та отриманих результатів встановлено, що у собак найчастіше проявляться симптоми ушкодження головного та спинного мозку, рідше - переферичні нейропаитії.

Перспективи подальших досліджень. На основі отриманих результатів буде проводитися верифікація діагнозу із застосуванням методів візуальної діагностики.

\section{Бібліографічні посилання}

Michael, D., Lorenz, Joan, R., Coares, Marc, Kenr et al. (2011). Handbook of veterinary neurology. ed 5, Elsevier

Levchenko, V I., Sudakov, M.O., Mel'nyk, J.L. (2004). Klinichna diagnostyka hvorob tvaryn. Bila Cerkva (in Ukrainian).

Braund, Kyle, G. (1994). Clinical syndromes in veterinary neurology.Mosby
Olbi, N. (2015). Nevrologicheskoe obsledovanie i lokalizacija povrezhdenij $\mathrm{v}$ spinnom mozge. Zh. Veterinarnyj Peterburg, 4-7 (in Russian).

Dewey, Curtis, W. (2008). A Practical Guide to Canine and Feline Neurology. Blackwell, USA.

Mark, T. Troxel, Kenneth, J. Drobatz, Charles, H. Vite (2005). Signs of neurologic dysfunction in dogs with central versus peripheral vestibular disease. Journal of the American Veterinary Medical Association. 227(4), 570-574

Tara, M. Ghormley, David, G. Feldman, James, R. Cook Jr. (2015). Epilepsy in dogs five years of age and older: 99 cases (2006-2011). Journal of the American Veterinary Medical Association. 246(4), 447-450.

Malte, Schwartz, Karen, R. Munana, Julie NettifeeOsborne (2013). Assessment of the prevalence and clinical features of cryptogenic epilepsy in dogs: 45 cases (2003-2011). Journal of the American Veterinary Medical Association. 242(5), 651-657.

Стаття надійшла до редакиї 10.10.2016 